\title{
Proceeding
}

Supplementary Issue: Winter Conferences of Sports Science. Costa Blanca Sports Science Events, 22-23 March 2021. Alicante, Spain.

\section{Pre-workout muscle vascularization and its effects on localized fat areas}

\author{
VINCENZO MASULLO ${ }^{1} \triangle$, FRANCESCO FISCHETTI², GIOVANNI ESPOSITO ${ }^{1}$, FRANCESCA D'ELIA ${ }^{1}$ \\ ${ }^{1}$ University of Salerno, Italy \\ ${ }^{2}$ University Aldo Moro of Bari, Italy
}

\begin{abstract}
Over the years the problem of spot reduction has often been addressed. Many fats regions tend to resist weight loss compared to others that have a greater vascularization; scientific evidence shows that blood flow in adipose areas is not high enough to allow the release of all fatty acids into the circulation. The objective of this essay is to prove how an adequate pre-workout muscle vascularization can have positive effects on the reduction of adipose tissue in less vascularized areas both in terms of time and effectiveness. Ten subjects will be examined divided into two groups (control group and experimental group) for the duration of twelve weeks, the experimental group will perform a pre-vascularization of the muscle district closest to the area of the adipose tissue taken under consideration, the control group instead, will skip this pre-vascularization phase. The progress of the two groups will be monitored until the end of the period under examination through anthropometric and plicometric tests. The expected results should confirm that adequate vascularization before training of the experimental group led to a greater and anticipated reduction of localized adipose tissue compared to the subjects of the control group who did not perform this method.
\end{abstract}

Keywords: Muscle vascularization; Fat; Spot reduction; Blood flow.

Cite this article as:

Masullo, V., Fischetti, F., Esposito, G., \& D'Elia, F. (2021). Pre-workout muscle vascularization and its effects on localized fat areas. Journal of Human Sport and Exercise, 16(3proc), S1023-S1030. https://doi.org/10.14198//hse.2021.16.Proc3.19

Corresponding author. University of Salerno, Italy.

E-mail: v.masullo7@studenti.unisa.it

Abstract submitted to: Winter Conferences of Sports Science. Costa Blanca Sports Science Events, 22-23 March 2021. Alicante, Spain.

JOURNAL OF HUMAN SPORT \& EXERCISE ISSN 1988-5202.

(c) Faculty of Education. University of Alicante.

doi:10.14198/jhse.2021.16.Proc3.19 


\section{INTRODUCTION}

Personal trainers from all over the world find themselves every day facing clients who ask to train only one part of the body, especially for the physical exercise in outdoor for the actual pandemic age (Raiola, Di Domenico, 2021, Raiola, Aliberti, 2021, Raiola et al., 2020). Despite to follow the good health status (Tiziana, et al., 2017), most of these requests come from girls who pursue a canonical model of beauty or who want to work only on the lower part of the body because of one of the many and false myths that haunt society that performing squats every day can help them to have more toned buttocks and to reduce water retention (Raiola, 2013) and for every aspects for physical activity and sport (Raiola, 2020ab). There is no shortage of male customers who, in view of the summer, present the absurd request to want a sculpted abdomen in three months. Over the years the problem of localized weight loss has often been addressed (Invernizzi et al., 2020). Many areas of fat tend to resist weight loss compared to others that instead have a greater vascularization (such as the arms). Scientific evidence shows that blood flow in adipose areas is not high enough to allow the release of all fatty acids into the circulation (Di Domenico et al., 2019) such as core muscle and biomechanics (Raiola et al., 2019, D'Elia et al., 2019) and in high intensity training (Raiola, D'Isanto, 2016). We therefore find ourselves facing a discourse that finds two opposing thoughts:

- who thinks it is possible to lose weight and tone by training only one part of the body?

- who thinks that a localized weight loss can never exist?

Science in this regard is still evaluating these theories but we are becoming more and more convinced that there may be a middle way but that it still needs to be researched for a long time and trying various strategies also in assessment (D'Isanto et al., 2019). In the article "Are blood flow and lipolysis in subcutaneous adipose tissue influenced by contractions in adjacent muscles in humans?" (Stallknecht et al., 2006) it was possible to analyse how there is a correlation between blood flow and the use of lipids in the subcutaneous adipose tissues as energy in the muscles adjacent to the contractions. The goal of this research was to see if lipolysis was higher in the subcutaneous adipose tissue (SCAT) adjacent to the contracting muscles than in the SCAT adjacent to the resting muscles. At the end of the research, it was found that blood flow and lipolysis were generally higher in the SCAT adjacent to the contraction than that adjacent to the resting muscle.

The problem to be faced is to create a protocol that allows to target the use of lipids in the area under consideration. Based on various research like: "Effect of combined resistance and endurance exercise training on regional fat loss" (Scotto di Palumbo et al., 2017) the objective of this study is to demonstrate how a right training method that manages to combine multiple strategies to promote blood flow and weight loss in areas where it is more difficult to lose weight than others can be more efficient of common training methods. In the present study, we aimed to emphasize the positive effect of the pre-workout muscle vascularization and its effects on localized fat areas by performing some exercises related to the muscles under consideration, in our case the rectus abdominis, before the start of the training session. To our best knowledge, this protocol has not been explored yet and we tested our hypothesis on a group of 10 healthy adults using anthropometric and plyometric tests.

\section{MATHERIAL AND METHODS}

\section{Subjects}

We examined 10 subjects ( 6 women and 4 men) aged between 20 and 25 years and a BMI between 22.5 and 27.3 , not physically active before the research, non-smokers and with a low rate of alcohol intake, divided randomly and equally into two groups (control group and experimental group) for the duration of 12 weeks 
with three weekly workouts, the experimental group will carry out a pre-vascularization of the muscle district closest to the fat area under examination, the control group will instead skip this pre-vascularization phase. The subjects were not aware of the type of group to which they belonged, and they were also instructed for the 5 days preceding the start of the research on the exercises they should have performed in order to have clearer executions from the first training. The HRmax of all subjects was also tested to customize the HIIT work they should have performed using the Karvonen formula and Bruce's test.

\section{Tools}

Heart rate monitors were also used to better calibrate the workload and monitor the subjects. The two groups performed anthropometric and plicometric tests on entry and after 4 weeks up to the twelfth. The measurement protocol included: an empty stomach for at least 12 hours and at least 36 hours from the last workout, for this reason all the measurements were made on Sunday morning at the end of each month. The tools used were plicometer and measuring tape.

\section{Research plan}

The training protocol of the experimental group included three sets of abdominals with ten repetitions each, of three different types (high knee crunch, Sit-up and reverse crunch on the ground).

At the end of these 3 exercises (not performed by the control group) used as a method of muscle prevascularization of the areas to be examined, we moved on to work on the treadmill in which both groups would have had to perform a HIIT workout designed for their capacity. HIIT, like other forms of Interval training (IT), represents a hybrid between aerobic and anaerobic training, as it works by exploiting the activation of different energy systems - aerobic and anaerobic systems (lactacid and alactacid) - based on constant variation intensity (D'Isanto et al., 2019; Pastore et al., 2019).

The HIIT training phase included:

1) Work at moderate intensity (60-70\% HRmax) for 3 minutes.

2) High intensity work (80-90\% HRmax) for 60 seconds.

3) Active recovery returning to moderate intensity for another 3 minutes $(60-70 \%$ HRmax).

For a total work of about 20 minutes.

Once this phase was completed, a classic anaerobic workout was carried out in the weight room, dividing the trained muscle groups for the 3 days of weekly training planned:

\begin{tabular}{|l|l|}
\hline Monday & Chest and biceps \\
\hline Wednesday & Legs and Shoulders \\
\hline Friday & Back and Triceps \\
\hline
\end{tabular}

At the end of the workout, various stretching exercises were also performed such as: Cobra pose, Cat-Cow pose, Child's pose (Altavilla, 2014).

At the end of the twelve weeks of training, the t-test was used: two paired samples for averages to analyse the results of the two training methods. 


\section{RESULTS}

To verify the validity of the proposed solution we adopt the statistical method of the t-test: two paired samples for means. Assuming a level of significance equal to $p<.05$, we assume as a null hypothesis $(\mathrm{HO})$ the one that the means of the two samples are equal or that in any case have a $p$ value such as to induce to attribute the differences found to casual; in case of impossibility to accept this hypothesis, we will be led to accept the alternative one ( $\mathrm{H} 1)$ which would confirm that any differences in the data collected by the skin measurements of the two different groups at the end of the period considered, are actually due to the administration of a different modality of work out.

\section{Experimental group}

Table 1. Data relating to the $\mathrm{mm}$ of fat lost by the subjects in the experimental group over 12 weeks.

\begin{tabular}{lccccc}
\hline Subject & $\begin{array}{c}\text { Abdominal fold } \\
\text { (beginning) }\end{array}$ & $\begin{array}{c}\text { Abdominal fold } \\
\text { (4 weeks) }\end{array}$ & $\begin{array}{c}\text { Abdominal fold } \\
\text { (8 weeks) }\end{array}$ & $\begin{array}{c}\text { Abdominal fold } \\
\text { (12 weeks) }\end{array}$ & $\begin{array}{c}\text { Mm of } \\
\text { fat lost }\end{array}$ \\
\hline S.L & 20 & 16 & 14 & 10 & 10 \\
S.B. & 21 & 17.4 & 15 & 10.3 & 10.7 \\
S.T. & 23 & 18.5 & 15.7 & 13 & 10 \\
S.D.S. & 16 & 13.5 & 12 & 9.8 & 6.8 \\
B.G. & 16 & 14.3 & 11 & 9 & 8 \\
\hline Average & 19.2 & 15.9 & 13.5 & 10.42 & 9.1 \\
\hline
\end{tabular}

\section{Control group}

Table 2. Data relating to the $\mathrm{mm}$ of fat lost by the subjects in the control group over 12 weeks.

\begin{tabular}{lccccc}
\hline Subject & $\begin{array}{c}\text { Abdominal fold } \\
\text { (beginning) }\end{array}$ & $\begin{array}{c}\text { Abdominal fold } \\
\text { (4 weeks) }\end{array}$ & $\begin{array}{c}\text { Abdominal fold } \\
\text { (8 weeks) }\end{array}$ & $\begin{array}{c}\text { Abdominal fold } \\
\text { (12 weeks) }\end{array}$ & $\begin{array}{c}\text { Mm of } \\
\text { fat lost }\end{array}$ \\
\hline M.N. & 23 & 21 & 17 & 15 & 8 \\
M.E.V. & 22 & 21 & 17 & 16 & 6 \\
M.A. & 22 & 20 & 17 & 14 & 8 \\
D.T. & 16 & 14 & 11 & 10 & 6 \\
A.S. & 17 & 15.5 & 13 & 10.6 & 6.4 \\
\hline Average & 20 & 18.3 & 15 & 13.12 & 6.8 \\
\hline
\end{tabular}

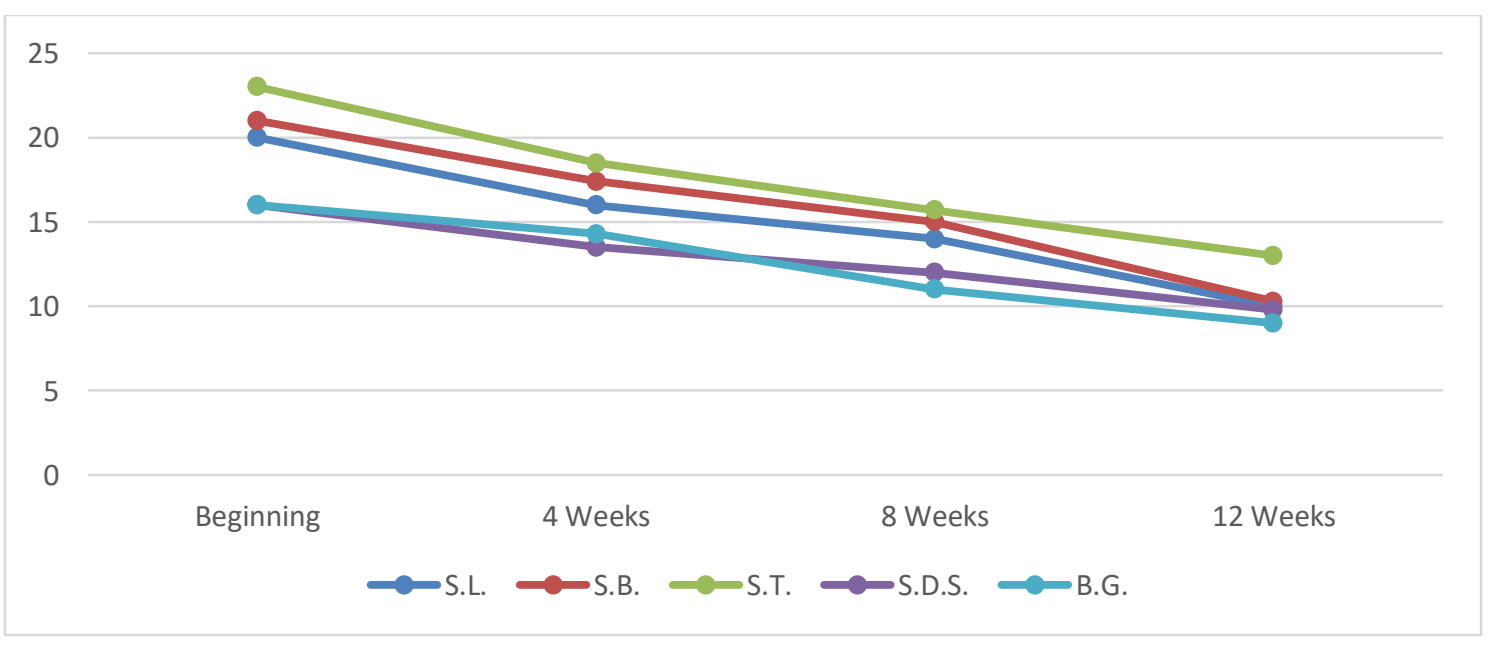

Figure 1. Graphical representation of the data in Table 1. 


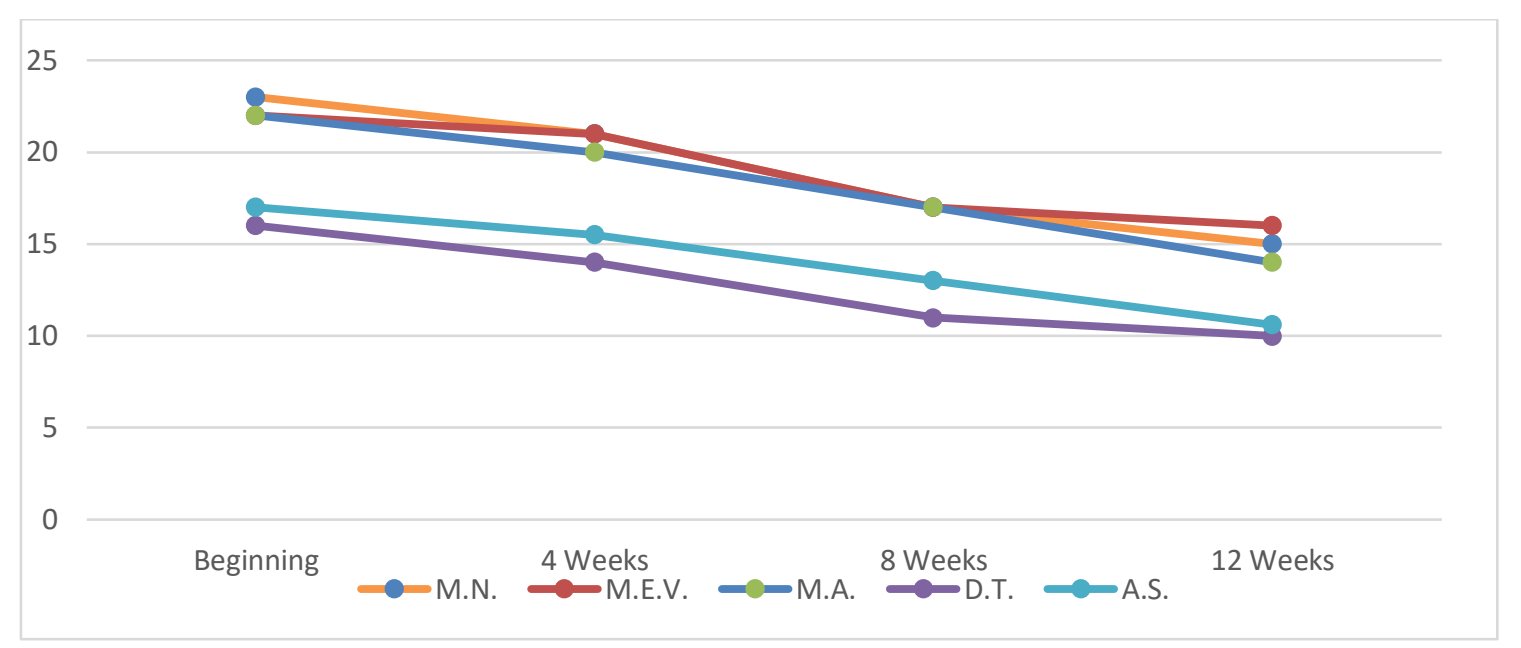

Figure 2. Graphical representation of the data in Table 2.

Table 3. T-test average mm of fat lost.

\begin{tabular}{|c|c|c|c|c|c|c|c|c|c|}
\hline \multicolumn{10}{|c|}{ Paired Samples Test } \\
\hline & & \multicolumn{5}{|c|}{ Paired Differences } & \multirow{3}{*}{$\mathrm{t}$} & \multirow{3}{*}{ df } & \multirow{3}{*}{$\begin{array}{l}\text { Sig. (2- } \\
\text { tailed) }\end{array}$} \\
\hline & & \multirow[t]{2}{*}{ Mean } & \multirow[t]{2}{*}{$\begin{array}{l}\text { Std. } \\
\text { Deviation }\end{array}$} & \multirow[t]{2}{*}{$\begin{array}{l}\text { Std. Error } \\
\text { Mean }\end{array}$} & \multicolumn{2}{|c|}{$\begin{array}{l}\text { 95\% Confidence } \\
\text { Interval of the } \\
\text { Difference }\end{array}$} & & & \\
\hline & & & & & Lower & Upper & & & \\
\hline Pair 1 & $\begin{array}{l}E G \\
C G\end{array}$ & 2.22000 & 1.47037 & .65757 & .39429 & 4.04571 & 3.376 & 4 & .028 \\
\hline
\end{tabular}

\section{DISCUSSION}

The main purpose of the present study was to test the effect of the protocol used on regional fat distribution. From the results obtained from our study we can evaluate how the experimental group managed to reach slightly better goals and, in less time, in fact we can see how despite the average of the abdominal folds at the start are very similar between the two groups $(19.2 \mathrm{~mm}$ and $20 \mathrm{~mm}$ ) after only 4 weeks the experimental group showed a mean decrease of $3.3 \mathrm{~mm}$ while the control group $1.7 \mathrm{~mm}$. After 8 weeks, the two groups approached $5.7 \mathrm{~mm}$ for the experimental group and $5 \mathrm{~mm}$ for the control group. Finally, at the twelfth week the difference between the mean $\mathrm{mm}$ of fat lost between the two groups reappeared with $9.1 \mathrm{~mm}$ for the experimental group and $6.8 \mathrm{~mm}$ for the control group. Analysing the T-test data we can see how the $p$ value falls within the significance level we set at the beginning of the study $(p<.05)$ and this allows us to be able to reject $\mathrm{H} 0$ in favour of $\mathrm{H} 1$, thus confirming the alternative hypothesis. We can also verify the value of $\mathrm{t}$ which, compared with the table of $t$ values for 4 degrees of freedom, is precisely aligned with that of the column $p=.05$, therefore the test is significant for $p<.05$. From the analysis of the data obtained from the frequent skin tests and from the positive response of the t-test we were able to confirm the objective from which we started at the beginning of this study. That is to demonstrate how a right training method that can combine more strategies to promote blood flow and weight loss in areas where it is more difficult to lose weight than others, is more efficient than common training methods (Di Domenico et al., 2020). The outcome of this study therefore allows us to have an extra tool for combating stubborn fat both in terms of efficiency and in terms of time. It is important to emphasize that the data acquisition test, that is skin measurement, has a margin of error due to various factors such as the skill of the operator or to different individual aspects such 
as the elasticity of the adipose tissue or skin thickness (Altavilla et al., 2018). Given the small number of subjects analysed, further studies are envisaged, perhaps increasing the number of subjects, and dividing them by sex in order to further support this training methodology, deepen its effects on both sexes and eliminate any doubts regarding its randomness.

\section{CONCLUSIONS}

The results confirmed that adequate vascularization before training of the experimental group led to a greater and earlier reduction of localized adipose tissue compared to the subjects of the control group who did not perform this method. The effectiveness of the training protocol carried out was confirmed.

\section{REFERENCES}

Altavilla, G., D'Isanto, T., Di Tore, A.P., Raiola, G. (2018). Free throw and outcomes: Pilot study on intensive training versus extensive one. Journal of Human Sport and Exercise, 13 (3):494-503. https://doi.org/10.14198/ihse.2018.133.02

Altavilla, G. (2014). Effects of the practice of muscle stretching [Učinci vježbanja stretchinga muskulature], Sport Science, 7 (1): 66-67.

Cataldi, S., Francavilla, V.C., Bonavolontà, V., De Florio, O., Carvutto, R., De Candia, M., Latino, F., Fischetti, F. (2021). Proposal for a fitness program in the school setting during the covid 19 pandemic: Effects of an 8-week crossfit program on psychophysical well-being in healthy adolescents. International Journal of Environmental Research and Public Health, 18 (6), art. no. 3141, pp. 1-12. https://doi.org/10.3390/ijerph18063141

D'Elia, D., Domenico, F.D., Isanto, T.D., Altavilla, G., Raiola, G. (2020) From biomechanics to motor learning, Acta Medica Mediterranea, 36 (5), pp. 3073-3078.

D'Isanto, T., D'Elia, F., Raiola, G., Altavilla, G. (2019) Assessment of sport performance: Theoretical aspects and practical indications. Sport Mont, 17 (1),79-82. https://doi.org/10.26773/smi.190214

Di Domenico, F. (2020) From biomechanics to learning: Continuum for the theory of physical and sports education, Journal of Human Sport and Exercise, 15 (Proc2), S268-S278. https://doi.org/10.14198/ihse.2020.15.Proc2.18

Di Domenico, F., Fattore, S., D'Isanto, T. (2019). The movement: Complexity and reductionism, evidence in comparison, Journal of Human Sport and Exercise, 14 (Proc4): 1-8. https://doi.org/10.14198//hse.2019.14.Proc4.18

D'Isanto, T., D'Elia, F., Raiola, G., Altavilla, G. (2019) Assessment of sport performance: Theoretical aspects and practical indications, Sport Mont, 17 (1), pp. 79-82. https://doi.org/10.26773/smj.190214

Fabre, O., Ingerslev, L. R., Garde, C., Donkin, I., Simar, D., \& Barres, R. (2018). Exercise training alters the genomic response to acute exercise in human adipose tissue. Epigenomics, 10(08), 1033-1050. https://doi.org/10.2217/epi-2018-0039

Hansen, D., Meeusen, R., Mullens, A., \& Dendale, P. (2012). Effect of acute endurance and resistance exercise on endocrine hormones directly related to lipolysis and skeletal muscle protein synthesis in adult individuals with obesity. Sports medicine, 42(5), 415-431. https://doi.org/10.2165/11599590$\underline{000000000-00000}$

Invernizzi, P.L., Signorini, G., Bosio, A., Raiola, G., Scurati, R. (2020). Validity and reliability of selfperception-based submaximal fitness tests in young adult females: An educational perspective. Sustainability (Switzerland), 12 (6), art. no. 2265. https://doi.org/10.3390/su12062265

Krotkiewski, M., Aniansson, A., Grimby, G., Björntorp, P., \& Sjöström, L. (1979). The effect of unilateral isokinetic strength training on local adipose and muscle tissue morphology, thickness, and enzymes. 
European journal of applied physiology and occupational physiology, 42(4), 271-281. https://doi.org/10.1007/BF00423297

Löberbauer-Purer, E., Meyer, N. L., Ring-Dimitriou, S., Haudum, J., Kässmann, H., \& Müller, E. (2012). Can alternating lower body negative and positive pressure during exercise alter regional body fat distribution or skin appearance?. European journal of applied physiology, 112(5), 1861-1871. https://doi.org/10.1007/s00421-011-2147-1

Mazzetti, S., Douglass, M., Yocum, A., \& Harber, M. (2007). Effect of explosive versus slow contractions and exercise intensity on energy expenditure. Medicine and science in sports and exercise, 39(8), 1291. https://doi.org/10.1249/mss.0b013e318058a603

Nankam, P. A. N., Blüher, M., Kehr, S., Klöting, N., Krohn, K., Adams, K., ... \& Goedecke, J. H. (2020). Distinct abdominal and gluteal adipose tissue transcriptome signatures are altered by exercise training in African women with obesity. Scientific reports, 10(1), 1-14. https://doi.org/10.1038/s41598020-66868-z

Pastore, F., Di Domenico, F., Viscione, I., D'elia, F. (2019). Assessment of aerobic resistance in the young soccer player. Journal of Physical Education and Sport, 19, art. no. 290, pp. 1953-1958.

Raiola, G., Di Domenico, F. (2021) Physical and sports activity during the COVID-19 pandemic, Journal of Physical Education and Sport, 21, art. no. 49, pp. 477-482.

Raiola, G., Aliberti, S. (2021) Outdoor sports and physical activity during social distancing by sports sciences and exercise course students at the university of Salerno, Journal of Physical Education and Sport, 21, art. no. 71, pp. 612-617.

Raiola, G., Domenico, F.D., Isanto, T.D., Altavilla, G., Elia, F.D. (2020)Biomechanics core, Acta Medica Mediterranea, 36 (5), pp. 3079-3083.

Raiola, G., Aliberti, S., Esposito, G., Altavilla, G., D'Isanto, T., D'Elia, F. (2020)How has the practice of physical activity changed during the covid-19 quarantine? a preliminary survey, Teoria ta Metodika Fizicnogo Vihovanna, 20 (4), pp. 242-247. https://doi.org/10.17309/tmfv.2020.4.07

Raiola, G. (2020a). Proposal of rearrangement of physical training and sport sciences methodology academic disciplines in Italian university body. Sport Science, 14 (1): 43-47.

Raiola, G. (2020b). The Movement and Sport Science in Italy towards the European Research Council. Physical Culture and Sport, Studies and Research, 86 (1):37-48. https://doi.org/10.2478/pcssr-20200011

Raiola, G. (2019) Comparison of exercise and sport sciences epistemology between european research council structure panel and Italian academic system, Sport Science, 12, pp. 112-120.

Raiola, G., D'isanto, T. (2016)Assessment of periodization training in soccer, Journal of Human Sport and Exercise, 11 (Proc1), pp. S267-S278. https://doi.org/10.14198/ihse.2016.11.Proc1.19

Raiola, G. (2013). Body knowledge and motor skills. Knowledge Cultures, 1 (6): 64-72.

Ramírez-Campillo, R., Andrade, D. C., Campos-Jara, C., Henríquez-Olguín, C., Alvarez-Lepín, C., \& Izquierdo, M. (2013). Regional fat changes induced by localized muscle endurance resistance training. The Journal of Strength \& Conditioning Research, 27(8), 2219-2224. https://doi.org/10.1519/JSC.0b013e31827e8681

Stallknecht, B., Dela, F., \& Helge, J. W. (2007). Are blood flow and lipolysis in subcutaneous adipose tissue influenced by contractions in adjacent muscles in humans?. American Journal of PhysiologyEndocrinology and Metabolism. https://doi.org/10.1152/ajpendo.00215.2006

Scotto di Palumbo, A., Guerra, E., Orlandi, C., Bazzucchi, I., \& Sacchetti, M. (2017). Effect of combined resistance and endurance exercise training on regional fat loss. The Journal of sports medicine and physical fitness, 57(6), 794-801.

Tiziana, D., Antonetta, M., Gaetano, A. (2017) Health and physical activity [Zdravlje i tjelesna aktivnost] Sport Science, 10 (1), pp. 100-105. 
Thompson, D., Karpe, F., Lafontan, M., \& Frayn, K. (2012). Physical activity and exercise in the regulation of human adipose tissue physiology. Physiological reviews. https://doi.org/10.1152/physrev.00012.2011

\section{(c)}

This work is licensed under a Attribution-NonCommercial-NoDerivatives 4.0 International (CC BY-NC-ND 4.0). 